\title{
Perhitungan Kebutuhan Daya Listrik untuk Penggerak Perahu Nelayan Bertenaga Surya
}

\author{
Iradiratu D.P.K ${ }^{1}$, Belly Yan Dewantara ${ }^{2}$ \\ Prodi Teknik Elektro, Fakultas Teknik dan Ilmu Kelautan \\ Universitas Hang Tuah Surabaya \\ iradiratu@hangtuah.ac.id, bellyyandewantara@yahoo.com
}

\begin{abstract}
Abstrak - Perahu merupakan salah satu armada yang digunakan para nelayan untuk mencari mata pencaharian. Namun pada umumnya pada saat perahu nelayan beropesi mengandalkan bahan bakar sebagai penggerak kapal, hal ini sangatlah tidak menguntungkan mengingat harga bahan bakar semakin mahal. Pada penelitian ini akan membahas desain dan perhitungan daya listrik penggerak perahu nelayan dimana enegi listrik didapat dari energi surya. Dengan adanya sistem pemanfaatan energi surya ini akan menghemat pengeluaran nelayan bahkan bisa dikatakan bahwa energi ini merupakan energi cuma-cuma atau gratis. Pada penelitian ini akan dihitung desain bodi perahu dengan kapasitas 2-3 orang, perhitungan kebutuhan alat penggerak, perhitungan kebutuhan energi listrik dan perhitungan panel surya yang akan digunakan. Hasil dari penelelitian ini dapat dijadikan kajian untuk pengembangan perahu ramah lingkungan, ekonomis, dan pemanfatan enegi surya yang merupakan energi terbarukan. Kapal yang dirancang mempunyai dimensi 3 meter dan lebar 1,33 meter dengan kecepatan 3-4 knot dan menggunakan panel surya dengan spesifikasi 150Wp sebanyak 3 buah.
\end{abstract}

Kata kunci: perahu nelayan, energi penggerak kapal, panel surya, energi terbarukan, MPPT

Abstract-Boat is one of the fleets that fishermen use livelihoods. But in general, when fishing boats oppose relying on fuel as a boat propeller, this is very unprofitable given the increasingly expensive. In this study will discuss the design and calculation of electric power driving a fishing boat where the electric energy is obtained from solar energy. Solar energy system will save fishermen's expenses. It can even be said that this energy is free energy. In this study the boat body design will be design with a capacity of 2-3 people, calculation of propulsion requirements, calculation of electrical energy requirements and calculation of solar panels to be used. The results of this research can be used as a study for the development of environmentally friendly, economical boats and the utilization of solar energy which is renewable energy. The ship was designed to have dimensions of 3 meters and 1.33 meters wide with a speed of 3-4 knots and uses 3 solar panels with capasity $150 \mathrm{Wp}$.

Keywords: fishing boat, boat propulsion energy, solar panel, renewable energy, MPPT

\section{PENDAHULUAN}

Indonesia merupakan negara maritime yang sebagian besar adalah perairan, dimana transportasi mengandalkan perahu. Selain digunakan sebagai transportasi laut perahu juga digunakan sebagai armada untuk mencari mata penghasilan bagi nelayan. Pada umumnya mesin penggerak perahu nelayan menggunakan BBM, selain menyebabkan polusi, harga BBM semakin mahal dan semakin sulit dijangkau oleh nelayan. Permasalahan tersebut diperuncing dengan adanya issue bahwa penghapusan subsidi untuk bahan bakar akan dihapus oleh pemerintah. Baterai/aki merupakan salah satu alternative energy listrik yang digunakan perahu nelayan sebagai sumber suplay daya listrik, cara ini sangatlah tidak efektif karena baterai hanya bertahan dalam waktu yang relatif pendek sehingga menghambat para nelayan untuk berlayar lebih jauh (muslim et al). Hal tersebut sangat berpengaruh pada perolehan hasil tangkap ikan yang tentunya berdampak pada ekonomi para nelayan.
Dari permasalah tersebut banyak penelitian pengembangkan energy alternative untuk penggerak kapal. Salah satunya yaitu dengan cara pemanfaatan energy surya (Sudiyono,2008), panas laut air laut, gelombang laut, dan angin (Santosa et al 2014). Dalam pemanfaatan energy terbaharui tersebut harusnya dilakukan secara terencana daya yang dihasilkan dan daya yang akan dibutuhkan oleh perahu agar operasional perahu dapat dilakukan dengan opimal. Perencanaan, perancangan dan perhitungan daya listrik sebagai sumber kelistrikan untuk penggerak, charging baterai, dan kelistrikkan lain harus dipersiapkan secara matang.

Pada penelitian ini akan dirancang dan dianalisis kebutuhan daya listrik perahu nelayan dengan spesifikasi perahu sebagai armada tangkap ikan ukuran kecil. Penelitian ini menghasilkan perhitungan dan rancangan kelistrikkan yang nantinya bisa digunakan sebagai solusi alternative bagi nelayan sebagai sumber energi penggerak perahu dengan pemanfaatan sumber energi yang ramah lingkungan. 
Dengan pemanfaatan energy surya sangatlah menguntungkan karena biaya operasional dapat ditiadakan bahkan tidak menimbulkan dampak polusi lingkungan.

\section{STUDI PUSTAKA}

Energi surya dapat dikonversikan secara langsung menjadi bentuk energi lain dengan tiga proses secara terpisah, yaitu proses heliochemical, proses helioelectrical dan proses heliothermal. Sedangkan konversi energi surya menjadi listrik termasuk proses helioelectrical. Proses ini dapat berlangsung jika dipergunakan fotovoltaik atau solar cell. Fotovoltaik adalah suatu alat yang digunakan untuk mengubah atau mengkonversi energi surya menjadi energi listrik searah, yang terbuat dari bahan semi konduktor (Santosa, 2014). Energi ditimbulkan oleh proses pemisahan electron dari struktur atomnya. Ini terjadi pada partikel kecil yang disebut dengan foton dimana foton merupakan partikel kecil dari sinar matahari. Ketika foton menabrak atom semikonduktor silicon solar cell maka timbulkan energy. Energy yang dihasilkan dari tenaga surya mempunyai beberapa kelebihan yaitu merupakan energy yang tidak habis pakai, pemeliharaan rendah, effisiensi yang tinggi, tidak menimbukan polusi dan biaya yang murah. Karena pertimbangan keunggulan diatas aplikasi energy surya banyak digunakan sebagai suplay energy sekarang ini. Salah satunya adalah penggunaan penggerak kapal. Dalam pemanfaatannya panel surya memerlukan beberapa komponen lainnya yaitu solar charge control dan baterai. Solar Charge Control (SCC) atau dikenal juga sebagai Battery Controller Unit ( BCU ) adalah peralatan elektronik yang berfungsi mengontrol tegangan dan arus dari solar sel ke baterai serta dari baterai ke beban. Battery ( accu ) berfungsi sebagai penyimpanan power yang dihasilkan oleh solar sel. Dengan kata lain arus yang mengalir dari solar sel akan disimpan ke dalam baterai atau accu, besar arus pengisian tergantung dari kapasitas solar sel, misalnya solar sel 50 WP arus yang masuk kebaterai sebesar 2,5 Ampere, dalam kondisi matahari panas. Jadi daya yang dihasilkan dan disimpan dalam baterai, tergantung dari jumlah panel solar sel dan baterai yang di butuhkan. Ukuran baterai yang akan digunakan untuk kebutuhan perahu, tergantung dari besarnya perahu ( motor ), semakin besar perahu ( motor ) semakin besar pula baterai yang digunakan.

Dalam perancangan perahu, penentuan ukuran utama perahu dapat dilakukan dengan menggunakan ratio perbadingan ukuran utama perahu agar mendapatkan sebuah perahu rancangan yang layak laut. Untuk rancangan perahu bertenaga surya ( solar boat ), ratio perbadingan ukuran utama yang digunakan seperti :

$$
\mathrm{L} / \mathrm{B}=3,0-4,0
$$

Ratio ini merupakan parameter hambatan perahu, semakin besar nilai rasio ini, hambatan perahu menjadi lebih kecil.

$$
\mathrm{B} / \mathrm{T}=2,7-4,8
$$

Rasio ini merupakanparameter stabilitas melintang perahu, semakin besar nilai rasio ini,stabilitas melintang perahu menjadi lebih besar.

Dimana : $\mathrm{L}=$ Panjang perahu $(\mathrm{m})$

$\mathrm{B}=$ Lebar perahu $(\mathrm{m})$

Dari ukuran utama perahu yang diperoleh dapat dihitung hambatan perahu (metode Guldhummar) untuk mengetahui seberapa besar daya yang akan digunakan pada kecepatan yang diinginkan [5].

\section{METODE}

Pemanfaatan energi surya untuk penggerak kapal yang dikembangkan pada penelitian ini dapat digambarkan pada gambar 1. Energy listrik didapat dari mengubah radiasi matahari menjadi listrik arus searah (DC) menggunakan semikonduktor yang menunjukkan efek fotovoltaik. Energi listrik yang dihasilkan akan dikoneksikan ke pengontrol sebagai pengatur tegangan dan arus dari panel surya dan kemudian disimpan kedalam baterai. Baterai yang telah menyimpan energy digunakan sebagai sumber daya untuk menggerakkan mesin penggerak perahu.
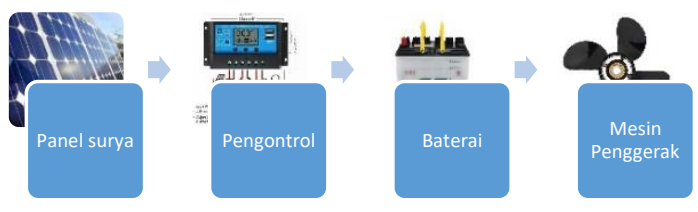

Gambar 1. Skema dasar system penggerak perahu menggunakan energi surya

Pembuatan body perahu menggunakan fiberglas dengan kapasitas dua orang, kapasitas baterai 12 volt, 100ah dan system kemudi perahu. Pada pemasangan komponen dilakukan seaman mungkin agar keamanan komponen terhadap air lebih terjaga. Kelebihan penggunaan energy surya adalah bersih, bebas polusi, menghasilkan listrik tanpa suara, minimum perawatan, tidak memerlukan investasi yang besar, dan tahan lama.

Pada tahap pengujian dilakukan perhitungan tahanan perahu, tahanan transom, tahanan total, dan tahanan gelombang. Pengujian juga dilakukan pada daya listrik dari energy surya dan laju pengirian pada baterai.

\section{HASIL DAN PEMBAHASAN}

Dalam penelitian ini dilakukan beberapa tahap mengerjaan yaitu melakukan perancangan badan perahu, perhitungan analisis kebutuhan listrik, perakitan komponen perahu dan instalasi, selanjutnya adalah pengujian dan analisis dari daya listrik perahu. 


\section{Perancangan body kapal}

Perahu dirancang dengan kapasitas dua orang, dengan panjang tiga meter dan kecepatan 3-4 knot. Perencaan tersebut sesuai dengan penelitian sebelumnya (Iradiratu dan Belly, 2019). Untuk perhitungan lebar, sarat dan tinggi perahu diperoleh dari persamaan :

$\mathrm{L} / \mathrm{B}=3,0-4,0$

$4 / \mathrm{B}=3,0$

$\mathrm{B}=1,3$ meter

Ratio tersebut merupakan parameter hambatan perahu, semakin besar nilai rasio maka hambatan kapal menjadi lebih kecil.

$\mathrm{B} / \mathrm{T}=2,7-4,8$

$1,3 / \mathrm{T}=3,00$

$\mathrm{T}=0,43$ meter

Lebar kapal kurang lebih 1,80 tinggi perahu sehingga tinggi perahu yang dirancang dapat diperoleh sebesar :

$\mathrm{B}=1,80 \mathrm{H}$

$\mathrm{H}=1,30 / 1,80$

$\mathrm{H}=0,72$ meter

Dengan demikian dapat disimpulkan bahwa ukuran utama perahu rancangan adalah sebagai berikut :
Panjang $(\mathrm{L}) \quad=4,0 \mathrm{~m}=400 \mathrm{~cm}$
Lebar (B ) $\quad=1,33 \mathrm{~m}=133 \mathrm{~cm}$
Sarat $(\mathrm{T}) \quad=0,43 \mathrm{~m}=43 \mathrm{~cm}$
Tinggi $(\mathrm{H}) \quad=0,72 \mathrm{~m}=72 \mathrm{~cm}$
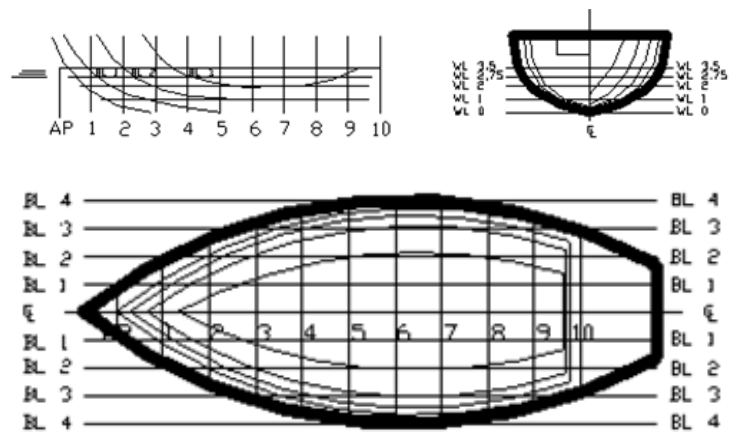

Gambar 2. Desain perahu nelayan

\section{Pemilihan motor penggerak kapal}

Penentuan dan pemilihan motor listrik pada penelitian ini menggunakan motor DC dengan tegangan $12 \mathrm{~V}$. Desain kelistrikan perahu yang dirancang dapat ditunjukkan pada gambar 3 .

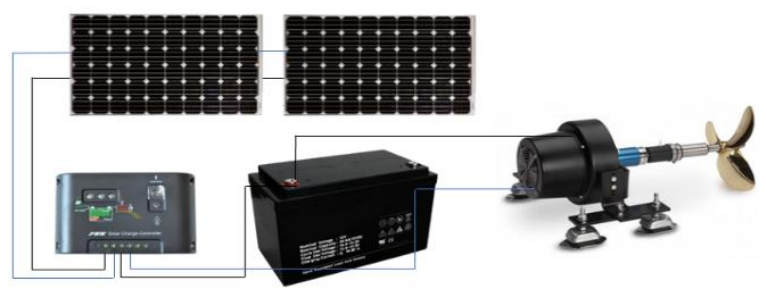

Gambar 3. Desain system kelistrikan
Pada gambar 3 dijelaskan bahwa energi yang didapat dari surya akan dikontrol dan distabilkan oleh rangkaian pentabil dan MPPT. Kemudian digunakan sebagai energi penggerak kapal dan energi disimpan dalam sebuah baterai. Gambar 4 merupakan motor yang digunakan sebagai penggerak kapal yaitu motor DC $12 \mathrm{~V}$ dengan kapasitas 450 watt.

Berdasarkan penelitian yang telah dilakukan motor penggerak tersebut dapat menghasilkan kecepatan kapal sekitar 3-4 knot. Kecepatan ini cukup sebagai penggerak kapal nelayan yang tidak membutuhkan kecepatan tidak terlalu tinggi.

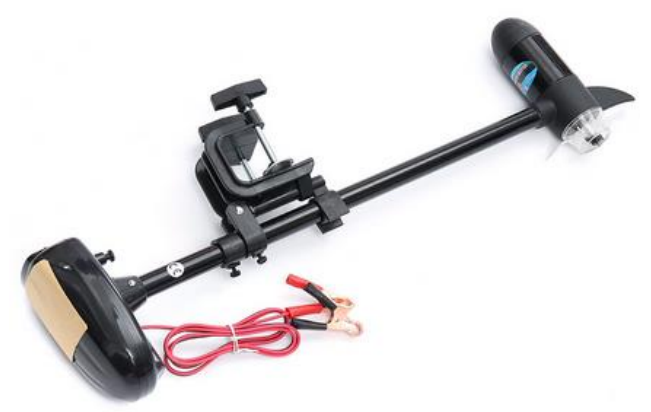

Gambar 4. Motor penggerak kapal

Penentuan spesifikasi panel surya sebagai sumber energi listrik kapal

Penentuan spesifikasi panel surya sangat diperlukan sebagai rancangan dasar penentuan energi yang dapat dimanfaatkan sebagai energi penggerak. Panel surya yang digunakan adalah jenis mono-crystalline dengan kapasitas $150 \mathrm{~W}$. Spesifikasi panel surya yang digunakan adalah sebagai berikut :

$150 \mathrm{~W}$ mono-crystalline Peak Power : $150 \mathrm{~W}$

Merk : Solarimba

Power Tolerance $(\%):+/-3 \%$

Cell Efficiency : $18 \%$

Open Circuit Voltage (Voc) : $21.6 \mathrm{~V}$

Short Circuit Current (Isc) : $6.1 \mathrm{~A}$

Maximum Power Voltage (Vmp) : $18 \mathrm{~V}$

Maximum Power Current (Imp) : 5.56 A

Number of Cell (Pcs) : 36 (4 x 9) Pcs

Operating Temperature (C) : $-40 \mathrm{C}$ to $+85 \mathrm{C}$

Dimensions (mm) : 1196 x 541 x $30 \mathrm{~mm}$

Spesifikasi tersebut diambil berdasarkan dari perhitungan penyerapan energy surya diasumsikan selama 4 jam, dan baterai yang digunakan 12 volt/15 Ah. Sehingga kapasitas baterai yang diperoleh sebesar 12 volt x 150 Ah yaitu 1.800 Watt. Kapasitas panel surya sebesar 1.800 Watt/4 jam 
sehingga didapat $450 \mathrm{Wp}$. Bedasarkan perhitungan tersebut maka menggunakan tiga buah panel surya untuk mendapatkan kapasitas $450 \mathrm{Wp}$. Mesin perahu nelayan didesain dapat beroperasi kurang lebih tiga jam maka total konsumsi daya oleh mesin tersebut adalah

Total beban $=3$ jam $x 500$ watt

$$
=1500 \text { watt }
$$

Kapasitas baterai $=1500 \mathrm{watt} / 12 \mathrm{volt}=125 \mathrm{Ah}$

Dari perhitungan dapat ditentukan kapasitas baterai yang harus tersedia minimal baterai $12 \mathrm{v}$ dengan kapasitas 125 Ah, sehingga dapat ditentukan menggunakan baterai/aki dengan kapasitas 12V / 150Ah = 1800 watt.

Untuk memaksimalkan pengerapan energi surya maka perlu juga dirancang sistem maximum point tracker (MPPT) yaitu sebuah rangkaian devais elektronik yang dapat memaksimalkan penyerapan energi surya berdasarkan penentian titik daya maksimal panel. Rangkaian Buck-boost converter juga dirancangan pada sistem ini yang akan berfungsi untuk menaikkan atau menurunkan level tegangan.

\section{KESIMPULAN}

Berdasarkan perhitungan pada penelitian ini dapat disimpulkan bahwa penyerapan energi surya dari panel surya dengan kapasitas $12 \mathrm{~V} / 150$ ah dengan perhitungan dasar penyerapan selama 4 jam dapat digunakan energi penggerak perahu nelayan. Energi ini dapat menggerakkan perahu nelayan sampai 3-4 knot dengan perahu dimensi panjang 4 meter dan lebar 1,33 m. Panel surya yang digunakan sebanyak 3 buah dengan spesifikasi $150 \mathrm{Wp}$. Kapasitas tersebut telah dapat digunakan sebagai suplai energi penggerak perahu nelayan. Dalam penyimpanan energi digunakan baterai jenis VRLA yang mempunyai kelebihan yaitu dimensi dan bobot baterai tersebut sehingga dapat menghemat ruang dan beban perahu. Berdasarkan penelitian ini disarankan penelitian berikutnya dapat dibangun kapal kapasitas yang lebih besar dengan memanfaatkan energi hibryd (surya dan gelombang laut)

\section{DAFTAR PUSTAKA}

[1] G.N.Tiwari dan Swapnil, Dubey. 2009. Fundamentals of Photovoltaic Modules and Their Aplications.

[2] Santosa, A.W.B. and Mulyatno, I.P., 2014. Pemanfaatan Tenaga Angin Dan Surya Sebagai Alat Pembangkit Listrik Pada Bagan Perahu. Kapal: Jurnal Ilmu Pengetahuan dan Teknologi Kelautan, 11(3), pp.108-116.

[3] Jha, A.R. (2010). Solar cell technology and applications, Taylor and Francis Group, LLC. London

[4] Sudiyono, S. and Antoko, B., 2008. Perancangan dan Pembuatan Kapal Wisata dengan Motor Generator Listrik Tenaga Surya Sebagai Energi Alternatif Penggerak Propeler. Jurnal Teknik Mesin, 10(1), pp.52-62.
[5] Jovendra. Heru., 2012. Rencana Bangun Kendaraan Listrik dengan Memanfaatkan Potensial Tenaga Surya. Skripsi. Universitas Indonesia.

[6] Hamdan, A., 2018. Desain Kapal Penumpang Bertenaga Surya Sebagai Sarana Transportasi di Pulau Gili Ketapang, Kabupaten Probolinggo (Doctoral dissertation, Institut Teknologi Sepuluh Nopember).

[7] Tiwari, G. N., \& Swapnil, D. (2009). Fundamentals of Photovoltaic Modules and Their Aplications.

[8] Winarni, D. (1997). Studi tentang perencanaan Captain, D. R. Derrett. (2001). Ship Stability for Masters and Mates, Fifth edition, Butterworth Heinema.

[9] IRHAM, E., 2013. Perancangan Pembangkit Listrik Hybrid Pada Kapal Penangkap Ikan Menggunakan Homer Di Selat Malaka (Doctoral dissertation, Universitas Islam Negeri Sultan Syarif Kasim Riau).

[10] Purwanto, D.B. and Utama, I.K.A.P., Kajian Pengembangan Kapal Wisata Berbasis Energi Alternatif: Kombinasi Layar dan Panel Surya. Kapal: Jurnal Ilmu Pengetahuan dan Teknologi Kelautan, 12(1), pp.25-30.

[11] F, Lumenta. (1997). Optimasi Dalam Penentuan Ukuran Pokok kapal-kapal Rakyat Di Maluku, Jurnal Ilmu Pengetahuan dan Teknologi Universitas Pattimura, Volume 2.

[12] Pulungan, A.B., Asnil, A., Hidayat, R., Sardi, J. and Islami, S., 2019. Pemanfaatan Motor Listrik Bertenaga Energi Matahari Sebagai Penarik Jaring Pada Kapal Nelayan. Jurnal Pendidikan Teknologi Kejuruan, 2(3), pp.85-89.

[13] Muslim, M. and Faturachman, D., PEMANFATAAN TENAGA SURYA SEBAGAI ALTERNATIF ENERGI TERBARUKAN UNTUK FASILITAS SUPLAI DAYA PENERANGAN DI KAPAL

[14] Putri, D.P. and Koenhardono, E.S., 2016. Perencanaan Sistem Pembangkit Listrik Hybrid (Sel Surya dan Diesel Generator) Pada Kapal Tanker. Jurnal Teknik ITS, 5(2), pp.B394-B399.

[15] Atallah Ahmed M, Almoataz Y, Abdelaziz, and Raihan S, Jumaah. 2014. Implementation of perturb and observe MPPT of PV System with direct control method using buck boost converters. Emerging Treends in Electrical, Electronics \& Instrumentation Engineering : An International Journal (EEIEJ), Cairo : Ain Shams University. 